\title{
COVID-19 AND IMPLEMENTATION OF AIRPORT HEALTH AND SAFETY PROCEDURES: THE SAFETY CULTURE PERCEPTION
}

\section{Wildan Nugraha dan Direstu Amalia}

Politeknik Penerbangan Palembang, Indonesia

Email: wildan.nugraha@poltekbangplg.ac.id dan direstu@poltekbangplg.ac.id

\begin{abstract}
The Covid-19 pandemic that is currently happening has become a scourge for the community and has had a quite wide impact on almost all industrial sectors, especially in the aviation industry. Government directions that require individuals to carry out social and physical distancing have made noteworthy changes to the flight forms and methods. The aim of this research is to assess the effect of implementing policies or regulations issued by the government regarding the handling of Covid-19 on aviation safety, especially in the airport operations sector. The approach of this research is descriptive qualitative, while data collection uses interview techniques and distributing questionnaires to airport personnel and airport management. This study resulted in findings that the aspect of aviation safety, especially for users of air transportation services, remains a top priority for airport operators even though during the Covid-19 pandemic, this is evidenced by the application of Biosafety Management and Biosecurity Management in the implementation of flight operations at airports. however, it is necessary to establish good collaboration and coordination with operators between modes of transportation other than aircraft in the airport area to prioritize the safety of users of transportation services by implementing health protocols.
\end{abstract}

Keywords: aviation safety; airport; covid-19; health protocol

\section{Introduction}

The Corona Virus Disease 2019 (Covid-19) case, which is a global pandemic, has raised concerns from various groups, especially in people's lives. The Covid-19 virus has had a major effect on the economic, social, and political environments in a number of countries, resulting in a shift in their interactions. Meanwhile, numerous countries have introduced various restrictions (such as closing land, sea, and air borders, reducing international air traffic, and so on) in order to minimize COVID-19's infectious impact (Azarafza, Azarafza, \& Akgün, 2020). Seeing the high level of the spread of covid-19, it requires the government to immediately take strategic steps. A number of approaches were taken by the government to anticipate the spread of covid-19, some of which is called social distancing. Social distancing is implemented by the government in order to limit human interaction and prevent people from crowding in arrange to maintain a strategic distance from the spread of covid-19 (Syarifudin, 2020). As for the policies

\begin{tabular}{|c|c|}
\hline How to cite: & $\begin{array}{l}\text { Wildan Nugraha dan Direstu Amalia (2021) Covid-19 And Implementation of Airport Health and } \\
\text { Safety Procedures: The Safety Culture Perception, Syntax Literate: Jurnal Ilmiah Indonesia. 6(4). } \\
\text { http://dx.doi.org/10.36418/syntax-literate.v6i4.2565 }\end{array}$ \\
\hline $\begin{array}{l}\text { E-ISSN: } \\
\text { Published by: }\end{array}$ & $\begin{array}{l}\text { 2548-1398 } \\
\text { Ridwan Institute }\end{array}$ \\
\hline
\end{tabular}


related to social restrictions set by the President of the Republic of Indonesia in a Press Conference held on March 31, 2020 in response to the corona pandemic in Indonesia, namely the Republic of Indonesia Law No. 6 of 2018 on Health Quarantine.

Therefore, the discussion of human mobility and pandemics is interesting because human mobility has become one of the main triggers of this pandemic. when the virus is very widespread, the visible impact is a tendency of reversed mobility, where there is a return of temporary migrants to their areas of origin. and second, mobility limitation in the form of restriction or cessation of mobility which then has an impact on other fields such as one of which is transportation, both land transportation, sea transportation and air transportation.

In this research the author focuses on the field of air transportation and takes samples of $x$ airport, which is one of the international airports in Indonesia, it can be landed by large aircraft on January 1, 1970. Development of the airport began on January 1, 1990. The comes about of this improvement made this airport can accommodate Boeing 747, Airbus A330, Boeing 777, and the like. In addition, passenger flow is projected to increase from 7,720 passengers to 16,560 passengers, which can result in high human mobility.

The safety factor is a priority in the world of aviation due to the large number of passengers flows at $x$ airport. with the aim of ensuring that passengers and flight crew are not disrupted during the flight by the air media, the aircraft they are in, or flight supporters from airport conditions, flight arrangements to operators on the air side and on the ground side (Nugraha, 2019). The indicators for implementing safety culture depend on the organization's vision and mission. This indicator cannot be determined by patents since culture is a nebulous term, in which each company has its own culture. Safety culture is formed by commitment of the management, communication, rules and procedures, competence, worker involvement, and the worker's social environment which can be seen from the perceptions of employee (Cooper, 2000).

Health protocol is a way that needs to be implemented to avoid the spread of cases of Covid-19 infection. This needs to be done because no specific antiviral that can be used as a vaccine has not been found (Di Gennaro et al., 2020). Seeing this, of course the public needs to know and apply several health protocols during the Covid-19 pandemic. Whereas in the Safety Management Manual document 9859 4th edition published by the ICAO it is stated that when the organization incorporates a positive safety culture, and this can be obviously upheld by upper- and middle management, front-line personnel. tend to experience a sense of mutual responsibility for achieving the organization's safety goals. Which in the statement is emphasized again on the recommendation that successful safety management enables a positive safety culture and a positive safety culture enables successful safety management.

To face the challenges of implementing a positive safety culture in the Covid-19 pandemic era, airports must continue to be consistent in carrying out flight operations that always prioritize safety and at the same time must also implement health protocols 
in handling this Covid-19. This is what attracts the author's attention to raise this theme in this study.

\section{Method}

This analysis employs a descriptive method and a qualitative approach, in which the researcher explores the application of regulations set by the government regarding the handling of the Covid-19 pandemic in the world of aviation in this case the aviation sector and then sees responses using google form media to airport personnel and management as implementers in the field related to the application of these regulations. This research is exploratory, so it does not aim to test hypotheses or make generalizations. The elements of this research design are based on the focus of the problem under study, the suitability of the object of research with theoretical references, informants, instruments, data collection procedures and data analysis. In qualitative research, researchers need to explain the occurrence of a phenomenon on the basis of the theoretical framework arranged during the research. Thus, researchers do not need to be hampered by the necessity to follow the theories contained in the various literature that have been built previously. Because it is possible that the existing theory does not match the facts it finds in the field (Nugrahani, 2014). Data collection using questionnaires and interviews. The interview is one of the data collection methods in research, especially qualitative research. There are several types of interviews that need to be understood, before deciding which one to use, depending on the research question to be answered. The type of question also describes the information to be obtained (Rachmawati, 2007).

\section{Result and Discussion}

Despite being affected by the Covid-19 pandemic, all airports must keep operating normally by always prioritizing safety, security, services and compliance with existing regulations. Along with this, $x$ Airport as one of the international airports in Indonesia is also required to put in place a range of steps to avoid the spread of Covid-19, as well as a number of company inventions, in line with regulator instructions.

So far, the implementation of preventing the spread of Covid-19 at the $\mathrm{x}$ airport refers to several regulations issued by the President, the Ministry of Transportation and the Covid-19 Handling Task Force. The regulations issued by the government regarding the handling of Covid-19 and related to the implementation of airport operations.

One of the regulations related to activities at airports is contained in the Regulation of the Minister of Transportation of the Republic of Indonesia Number PM 41 (2020) concerning transportation control in the context of preventing the spread of Corona Virus Disease 2019 (Covid-19), which in article 14 of the regulation reads: Control of transportation activities as referred in Article 10 paragraph (1) for air transportation includes: (a) the airport capability (slot time) was modified based on evaluation; and (b) limiting the number of passengers from the total seating capacity by implementing physical distancing. 
Based on Circular Number 32 of 2020 that every airport operator, in this case including the $\mathrm{x}$ airport manager, must follow the following conditions: (a) Support the implementation of the Task Force Circular; (b) Establishing guard and inspection posts at each airport equipped with health protocol implementation facilities and coordinating with the Airport Authority, Port Health Office (KKP), Police, TNI, Regional Government, Regional Covid-19 Task Force and other Related Agencies; (c) Support the provision and implementation of slot time recommendations if air transport business entities make changes to flight schedules; (d) Carry out activities with reference to health protocols and Regulation of the Minister of Transportation of the Republic of Indonesia Number PM 18 (2020) concerning Control of Transportation in the Context of Preventing the Spread of Covid-19.

As for its implementation, the $\mathrm{x}$ Airport has made efforts to ensure that all activities in the airport are in accordance with applicable regulations. Therefore, to ensure that the data obtained was valid, the authors conducted field observations. Based on the results of the author's observations regarding the implementation of the Health protocol that has been carried out by the $\mathrm{x}$ airport, it can be shown in the pictures below.

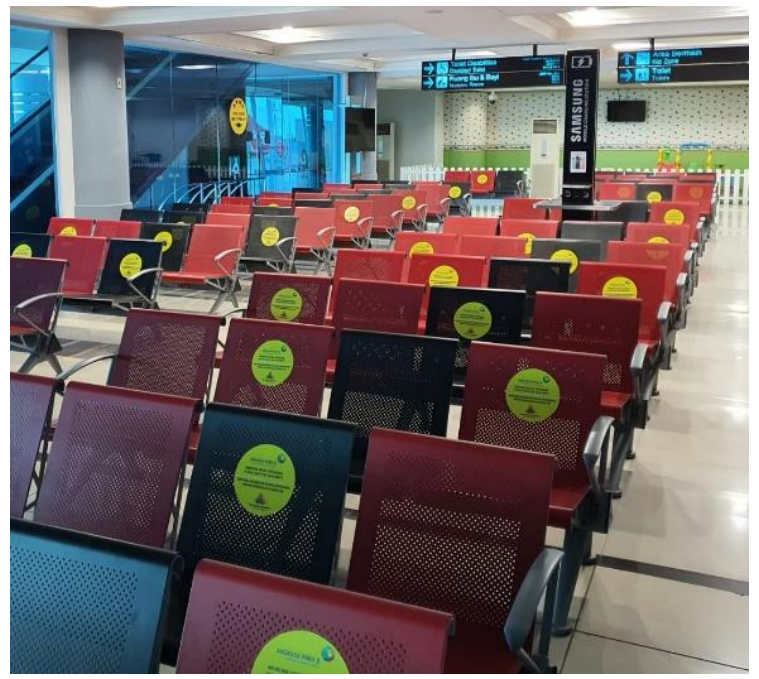

Figure 1

The application of physical distancing in the departure waiting room

Implementing physical distancing or maintaining distance is one of the efforts made by the $\mathrm{x}$ airport operator to minimize the level of covid-19 transmission. Physical distancing, also known as restricting physical contact, is a collection of nonpharmaceutical infection prevention steps aimed at preventing or slowing the spread of infectious diseases. The main aim of this restriction strategy is to minimize the risk of physical contact between an infected person and other uninfected individuals, in order to reduce disease transmission, infection transmission, morbidity, and other harmful effects that may lead to death (Yunus \& Rezki, 2020). Therefore, each seat in the departure hall and arrival hall at $\mathrm{x}$ airport is given a distance by placing a dividing sticker. 


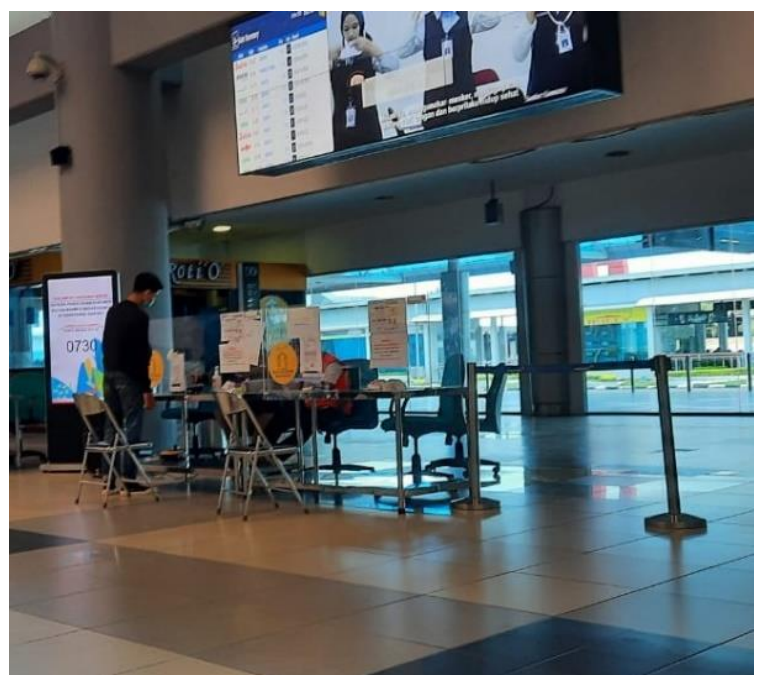

Figure 2

\section{Verification of the rapid test / PCR certificate at the departure terminal.}

One of the requirements for prospective passengers to be able to use flight services is to attach a covid-19 free certificate. the inclusion of the covid-19 free certificate has become national policy of the Republic of Indonesia. Everyone traveling using public transportation, in this case an airplane, is required to attach these results. Therefore, before carrying out check-in activities, all prospective passengers must verify their rapid test / PCR certificate at the Health Office post located within the departure terminal at $\mathrm{x}$ airport.

At the arrival terminal, activities for handling or preventing the transmission of covid-19 are also carried out. One of the efforts is to place temperature monitoring devices and checking officers to fill in the e-HAC application from the local health office. e-HAC itself stands for Electronic - Health Alert Card, namely the Health Alert Card, a modern version of the manual card used previously. This application serves to quickly access all potential visitors who will come to an area either through the sea port or the airport gate. it can be seen that the implementation of the Health protocol in $\mathrm{x}$ airports both at the departure and arrival terminals has been running quite well, both for checking passengers from the boarding process to passengers who have just landed.

Aviation safety relates to the use of airspace, aircraft, airports, air transportation, flight navigation, and other supporting services and public facilities in compliance with safety regulations (Amalia, 2019). Therefore, aviation safety is an important aspect that should not be ignored. This has become one of the challenges of aviation during the current pandemic not to become a means of transmitting Covid-19.

At $x$ Airport, the safety aspect is still a priority in airport management. This was emphasized by the Senior Vice President of Corporate Safety and Risk in the Annual Safety Report of, who stated that Safety is part of the company's way of selling airport service products to customers, maintaining and protecting corporate strategic programs 
in accordance with one of company missions. namely, ensuring safety and security are the top priority.

One of the challenges faced by the Airport Safety Unit of $\mathrm{x}$ airport in implementing the Safety Management System during a pandemic is a decrease in the frequency of movement of both aircraft and passengers. This decrease was influenced by the implementation of the Regulation of the Minister of Transportation Number PM $41 / 2020$, especially regarding the adjustment of airport capacity (slot time) which resulted in reduced aircraft movement. In addition, the implementation of the Covid-19 handling regulations coupled with changes in the culture of the people who tend to avoid public transportation has a significant impact on flight operations at $\mathrm{x}$ airport. Therefore, the authors summarize the reduction in the number of aircraft and passenger movements as shown in the diagram below.

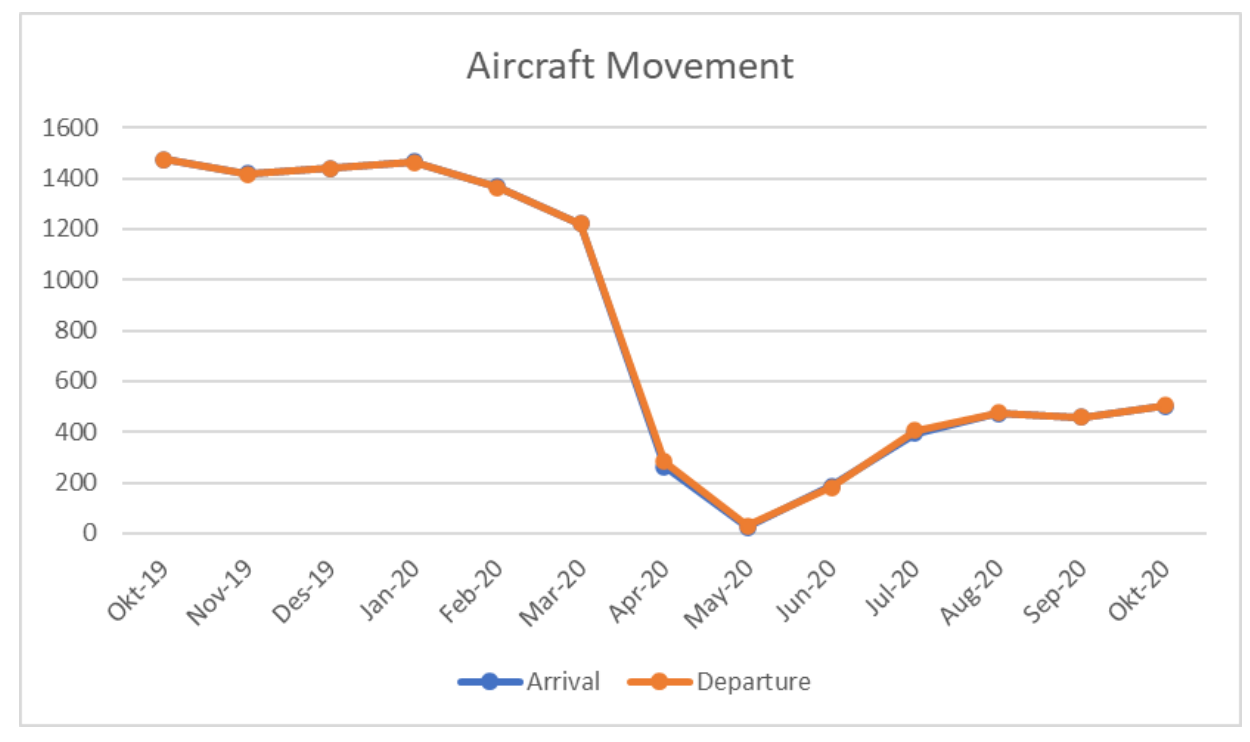

Figure 3

Number of Aircraft Movements from Oct-19 to Oct-20

In the period October 2019 to October 2020 there was a decrease in aircraft movements which was considered quite significant in April 2020 which experienced a decrease in the number of arrivals by $78.5 \%$ and in the number of flight departures by $76.7 \%$ from the movement of the previous month. As for the movement of the number of passengers as shown in the diagram below. 


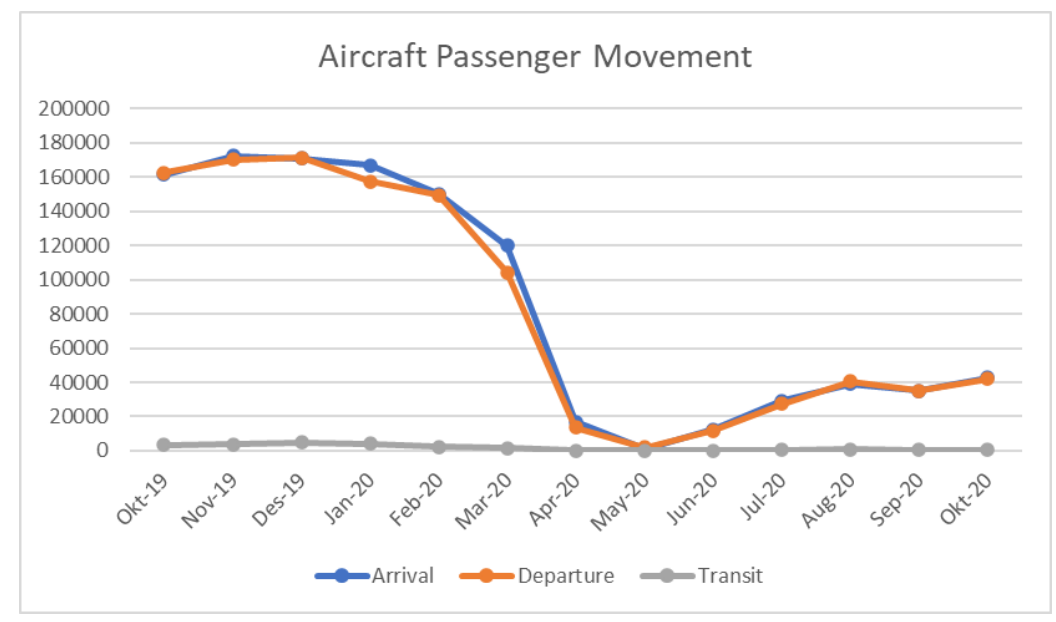

Figure 4

Number of Passenger Movements from Oct-19 to Oct-20

In line with aircraft movements, there was also a significant decrease in passenger movements in April 2020. The reduction in the number of passenger arrivals was $86 \%$, the number of passenger departures decreased by $87.1 \%$ and the total reduction in transit passengers was $86.9 \%$ in the previous month.

In order to complete the required data and assess the scope of the Safety Management System's implementation at the $\mathrm{x}$ airport, researchers also conducted interviews with safety officers, where the results of the interviews could be taken into consideration in conducting a gap analysis. The interview method used in this research is face-to-face interviews, with the format of the questions for this interview, the researcher refers to the SMS Assessment Checklist contained in the ICAO 9859 document. The questions given only focus on the application of SMS in airport operators when facing the Covid-19 pandemic, in addition to the researchers also added several questions related to existing conditions. Interviewed interviewees can choose Yes, No, or Partial and provide answers to what they choose. And what should be noted is that there is still a lack of handling of health protocols in other modes or shifting modes of transportation, such as trains, taxis and other public transportations. Related to this, it is necessary to have good collaboration between stakeholders outside the airport in promoting the safety of transportation service users in general.

To deepen this research, the authors trace the survey data that has been conducted by the Central Bureau of Statistics (Badan Pusat Statistik, 2020) regarding the implementation of health protocols in public transportation other than airplanes, where the results of the survey are presented in the diagram below. 


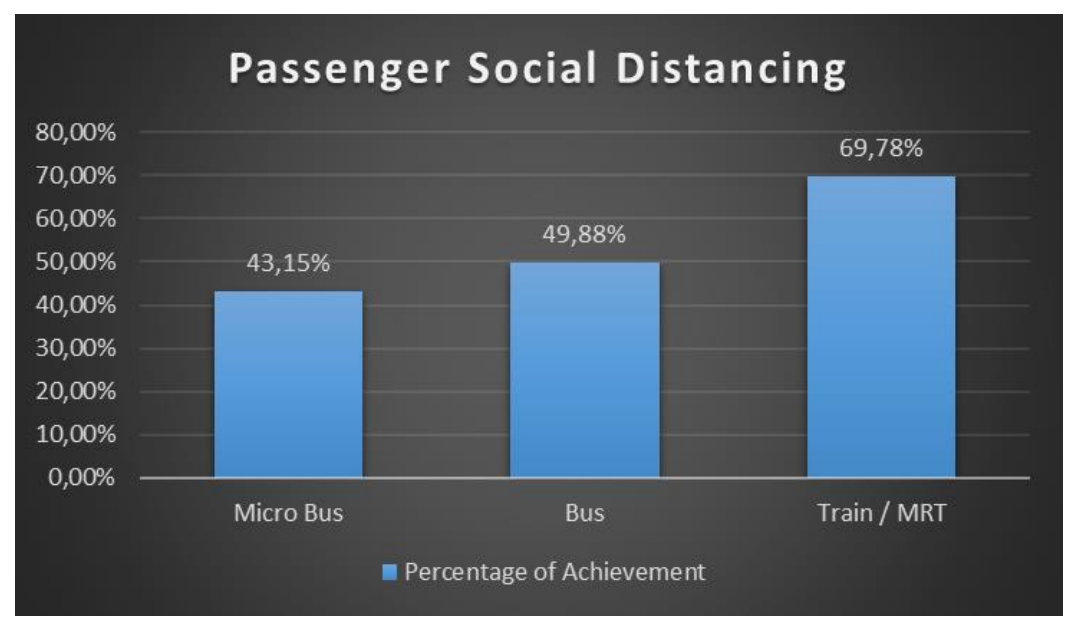

Figure 6

Implementation of Social Distancing in transportation modes other than aircraft

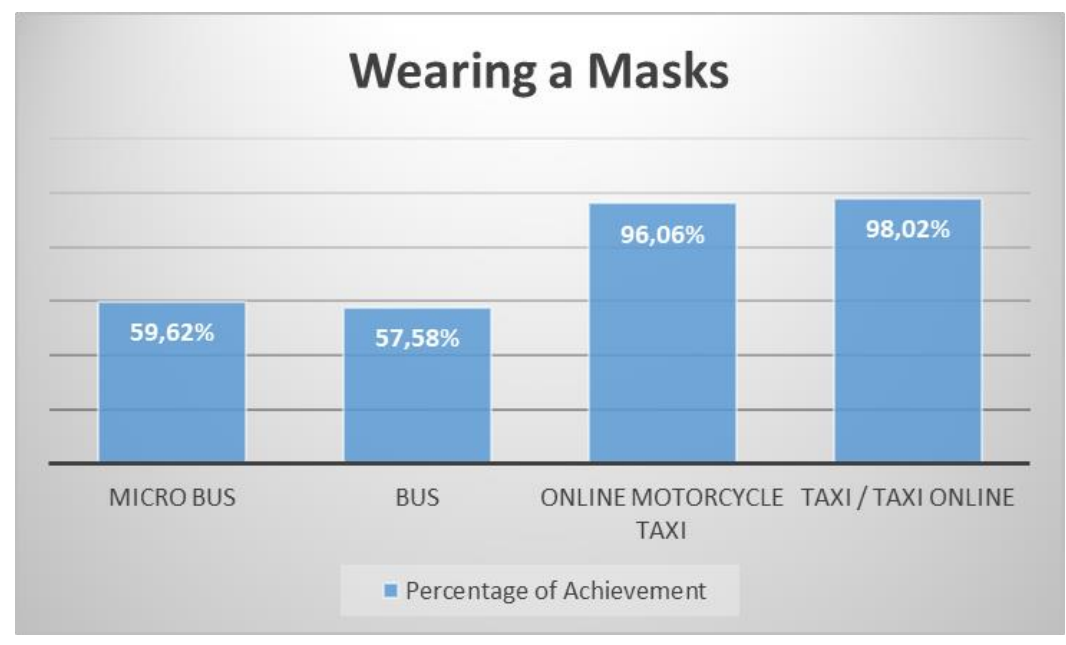

Figure 7

Implementation of wearing a mask in transportation modes other than aircraft

From the data above, the application of health protocols in modes of transportation other than airplanes is actually lower with the average value for Social Distancing at $54,2 \%$ and the use of masks on public transportation other than online based is at an average value $58,6 \%$. This could be an indication that the level of risk of covid-19 transmission in areas of transportation mode transfer is quite high due to the lack of application of health protocols in these areas.

Meanwhile, this condition is inversely proportional to the health protocol in the airport itself, which is quite strict with the supervision and pressure from the regulator 
and operator of the airport itself. So that the level of risk of contracting covid-19 in the airport area is at a low level. Based on these conditions, Mulyono (2020) illustrates these conditions as in the image below.

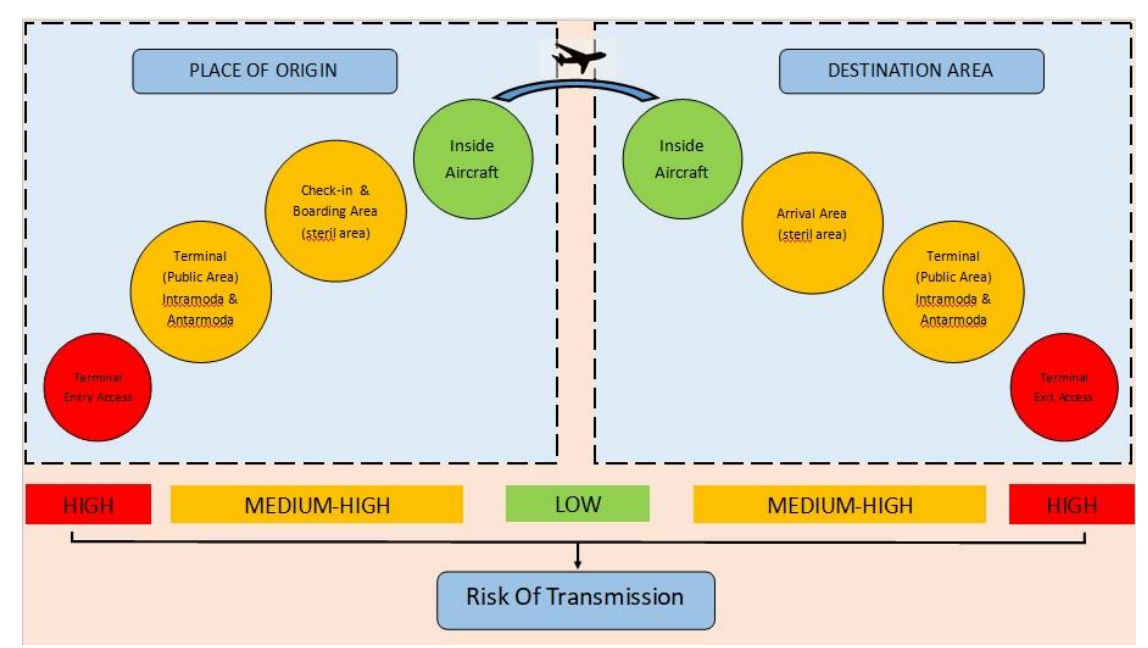

Figure 8

Potential Risk of Covid-19 transmission between transportation zones

This can happen because of steps that have been taken by the $\mathrm{x}$ airport operator in improving the aviation safety culture during the Covid-19 pandemic that the authors have successfully noted are as follows:

The first effort, $\mathrm{x}$ airport management together with stakeholders, have jointly implemented the health protocol strictly starting March this year, then since July until this article was written, it started to launch the Safe Travel Campaign.

Biosecurity Management has strengthened the health protocol at $\mathrm{x}$ Airport, including Health Screening, Physical Distancing, Facility Cleanliness \& Sanitizing, Passenger Touchless Processing and People Protection. In addition, $\mathrm{x}$ airport has also implemented the implementation of Biosafety Management which includes Environment Screening, Virus Spreading Anticipation, Public Health Assurance and Infrastructure Sterilization.

In the next stage, the implementation of health protocols at $\mathrm{x}$ airport, was strengthened by the implementation of the Safe Travel Campaign which focuses on consistency, increases public confidence and strengthens collaboration between stakeholders. These three points need to be disseminated in a comprehensive manner so that all people as users of transportation services know it.

The next effort is to improve the Airport Safety Reporting System, which is a system that regulates the procedures for reporting hazards, incidents and accidents related to aircraft operations at airports and reports on occupational health and safety for employees of x Airport.

Whereas in the Safety Management Manual document 9859 4th edition (2018) published by the ICAO it is stated that when the organization incorporates a positive safety culture, and this can be obviously upheld by upper- and middle management, 
front-line personnel. tend to experience a sense of mutual responsibility for achieving the organization's safety goals. Which in the statement is emphasized again on the recommendation that successful safety management enables a positive safety culture and a positive safety culture enables successful safety management.

This system supports the safety management system's implementation that implemented by each airport operator, and also fulfills the Regulation of the Director General of Civil Aviation number: KP 242 of 2017 and KP 245 of 2017 and Government Regulation Number 50 of 2012 concerning Application of Occupational Health and Safety Management Systems.

Submission of reports related to Voluntary Reports at $\mathrm{x}$ airport can be submitted through the reporting media that has been provided, including by telephone or short message (SMS), E-mail, Letter (Form) and the Online Safety Reporting System (OSRS). so that it makes it easier for all reporters to submit direct reports of events related to hazards, incidents, accidents and work accidents in the work environment of $\mathrm{x}$ airport which could potentially endanger employees and other airport service users. Below is one of the reporting media displays through the Online Safety Reporting System (OSRS).

To find out how often airport personnel report the hazards they find in their daily work environment, the authors randomly distributed questionnaires to several respondents, namely personnel working on the air side with the following results.

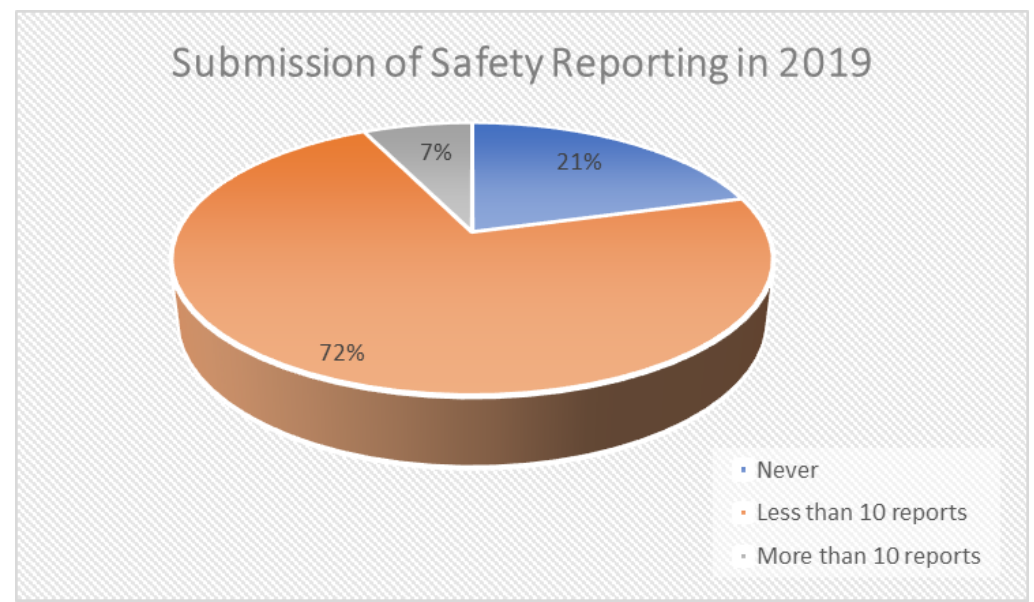

Figure 9

Submission of Safety Reporting in 2019

The most frequently reported hazards in 2019 were related to foreign object debris (FOD), water ponding, obstacle, mark/signage and so on which could potentially endanger flight operations. The reporters are mostly from internal parties at the $\mathrm{x}$ airport itself, namely from the safety inspector and personnel on the air side. The factors forming a safety culture that were included in the good category were commitment, procedures and rules, the social environment of workers and communication. 
Meanwhile, what is included in the fairly good category is worker involvement (Rizaldy \& Setiawan, 2015).

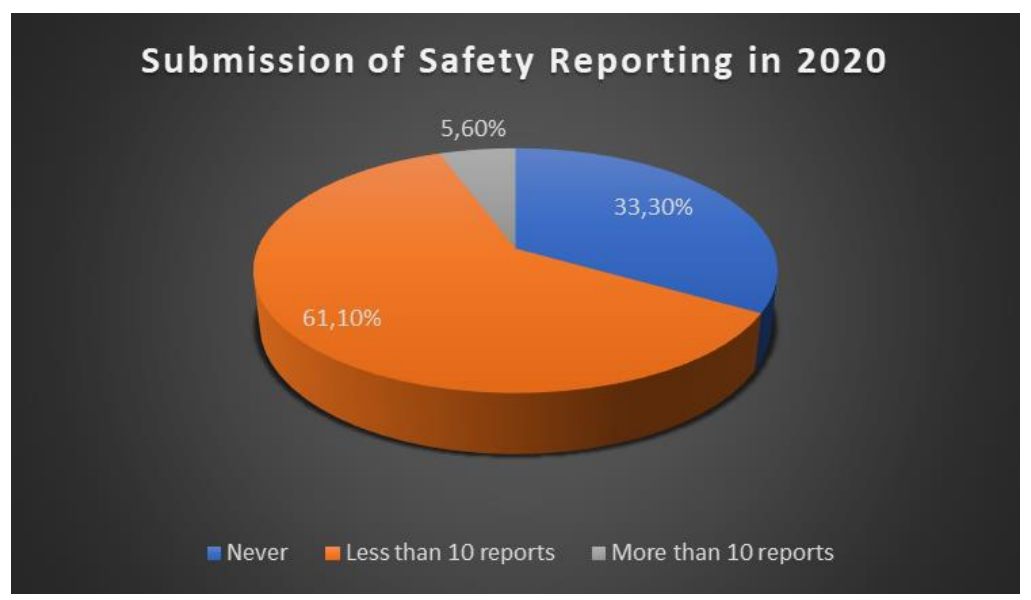

Figure 10

Submission of Safety Reporting in 2020

From the two pictures above, there is data on personnel who became respondents who submitted Safety Reports, more than 10 (ten) reports in 2019 decreased by 10,9\%, while respondents who submitted reports of less than 10 (ten) reports from 2019 to 2020 decreased as much as $1,4 \%$, while the data of respondents who had never submitted a report increased by $12,3 \%$. This indicates a decrease in the number of safety report reporters from the period before the Covid-19 pandemic to the time of the Covid-19 pandemic which could be caused by a decrease in aircraft movements due to restrictions on the movement of people during the Covid-19 pandemic, where the first case of Covid-19 was confirmed in Indonesia in the first quarter of that year.

\section{Conclusion}

Based on the results of the analysis that the author carried out at $x$ airport, it can be concluded that the aspect of aviation safety, especially for users of air transportation services at $\mathrm{x}$ airport, remains a top priority for the operator even though during the Covid-19 pandemic like today. This is evidenced by the implementation of various efforts to prevent the spread of Covid-19 in accordance with the instructions of the government of the Republic of Indonesia, and what should be noted is that there is still a lack of handling of health protocols in other modes of transportation, such as trains, taxis and other public transportation in the airport area. This is due to the absence of integrated collaboration and coordination between stakeholders outside the airport in prioritizing the safety of transportation service users in general. 
Covid-19 And Implementation of Airport Health and Safety Procedures: The Safety Culture Perception

\section{BIBLIOGRAFI}

Amalia, Direstu. (2019). Promoting just culture for enhancing safety culture in aerodrome airside operation. International Journal of Scientific and Technology Research, 8(10), 260-266. Google Scholar

Azarafza, Mehdi, Azarafza, Mohammad, \& Akgün, Haluk. (2020). Clustering method for spread pattern analysis of corona-virus (COVID-19) infection in Iran. MedRxiv, 3(1), 1-6. https://doi.org/10.1101/2020.05.22.20109942 Google Scholar

Badan Pusat Statistik. (2020). Survei Perilaku Masyarakat Di Masa Pandemi. Google Scholar

Cooper, M. D. (2000). Towards a model of safety culture. Safety Science, 36(2), 111136. Google Scholar

Di Gennaro, Francesco, Pizzol, Damiano, Marotta, Claudia, Antunes, Mario, Racalbuto, Vincenzo, Veronese, Nicola, \& Smith, Lee. (2020). Coronavirus diseases (COVID19) current status and future perspectives: A narrative review. International Journal of Environmental Research and Public Health, 17(8). https://doi.org/10.3390/ijerph17082690 Google Scholar

International Civil Aviation Organization. ICAO Doc 9859 4th Edition - Safety Management Manual. , (2018). Google Scholar

Mulyono, A. T. (2020). Keselamatan penerbangan di masa pandemi COVID-19. Conference SENATIK STT Adisutjipto Yogyakarta, 1-2. Google Scholar

Nugraha, Wildan. (2019). Safety documentation: A communication approach for safety management system in aerodrome operator. International Journal of Scientific and Technology Research, 8(11), 1705-1711. Google Scholar

Nugrahani, Farida. (2014). Dalam Penelitian Pendidikan Bahasa. 信阳师范学院, l(1), 305.

Peraturan Menteri Perhubungan RI. Peraturan Menteri Perhubungan Republik Indonesia Nomor PM 18 Tahun 2020 tentang Pengendalian Transportasi Dalam Rangka Pencegahan Penyebaran Corona Virus Disease 2019 (Covid-19). , (2020).

Peraturan Menteri Perhubungan RI. Peraturan Menteri Perhubungan Republik Indonesia Nomor PM 41 tahun 2020 tentang pengendalian transportasi dalam rangka pencegahan penyebaran Corona Virus Desease 2019. , (2020).

Rachmawati, Imami Nur. (2007). Pengumpulan Data Dalam Penelitian Kualitatif: Wawancara. Jurnal Keperawatan Indonesia, 11(1), 35-40. https://doi.org/10.7454/jki.v11i1.184 Google Scholar

Rizaldy, W., \& Setiawan, A. (2015). Kompetensi Dan Kualitas Layanan Karyawan 
Wildan Nugraha dan Direstu Amalia

Terhadap Keselamatan Penerbangan. Jurnal Manajemen Bisnis Transportasi Dan Logistik, 1(2), 177-192. Google Scholar

Syarifudin, Albitar Septian. (2020). Impelementasi Pembelajaran Daring Untuk Meningkatkan Mutu Pendidikan Sebagai Dampak Diterapkannya Social Distancing. Jurnal Pendidikan Bahasa Dan Sastra Indonesia Metalingua, 5(1), 31-34. https://doi.org/10.21107/metalingua.v5i1.7072 Google Scholar

Yunus, Nur Rohim, \& Rezki, Annissa. (2020). Kebijakan Pemberlakuan Lock Down Sebagai Antisipasi Penyebaran Corona Virus Covid-19. Salam: Jurnal Sosial Dan Budaya Syar-I, 7(3), 227-238. Google Scholar

\section{Copyright holder:}

Wildan Nugraha dan Direstu Amalia (2021)

First publication right:

Journal Syntax Literate

This article is licensed under: 